\title{
PENGGUNAAN MULTIMEDIA DALAM PEMBELAJARAN BAHASA JEPANG PRAKTIS PADA KARYAWAN OBJEK WISATA SUMARU ENDO KECAMATAN REMBOKEN
}

\author{
Sandra Rakian \\ Fakultas Bahasa dan Seni \\ Universitas Negeri Manado
}

\begin{abstract}
ABSTRAK
Kegiatan pengabdian pada masyarakat dalam bentuk Penggunaan multimedia dalam pembelajaran Bahasa Jepang Praktis pada karyawan objek wisata sumaru endo Kecamatan Remboken telah dilaksanakan dengan baik. Pelaksanaan pelatihan ini telah mencapai tujuan yang direncanakan karena semua peserta dapat menguasai dan menggunakan bahasa Jepang dan tulisan Jepang yang sederhana guna untuk menunjang karyawan dalam (berkomunikasi )pelayanan wisata khususnya tamu orang Jepang. Dengan melihat keberhasilan yang diperoleh serta animo peserta maka disarankan agar kegiatan pengabdian pada masyarakat dalam bentuk pelatihan berupa kursus singkat seperti ini perlu dilanjutkan baik pada lokasi yang sama maupun pada lokasi yang lain dengan topik/materi yang berkelanjutan (Bahasa Jepang) ataupun bahasa asing lainnya.
\end{abstract}

Kata Kunci: Pengabdian, Bahasa, Jepang 


\section{PENDAHULUAN}

\section{A. Analisis Situasi:}

Penggunaan multi media dalam Pembelajaran bahasa Jepang Praktis sebagai bahasa kedua dilingkungan pendidikan formal maupun non formal menjadi satu hal yang sangat penting. Karena selain akan menjadi kompetensi tersendiri bagi si pembelajar untuk digunakan sebagai bahasa pengantar dalam mewujutkan komunikasi dengan pemakai bahasa sumber tetapi juga sebagai alat untuk membangun komunikasi antar bangsa dalam rangka tujuan kerja sama antar Negara. Di sisi lain ketika kita mau mengembankan orientasi pada budaya, seni, ilmu pengetahuan dan teknologi di Negara lain maka di perlukan bahasa pengantar dalam hal ini bahasa asing/ bahasa Jepang. Fukada (1997:V111). Belajar Bahasa asing memang berharga karena membuat anda berhubungan dengan orang asing, baik sebagai alat praktis dalam kehidupan seharihari.

Dalam pencapaian tujuan pembelajaran bahasa asing maka fungsi bahasa asing secara umum haruslah berdasarkan pada tujuan pendidikan yaitu berfungsi sebagai alat untuk membentuk manusia pancasila yang trampil dan membangun, olehnya harus dikuasai bahasa asing khususnya bahasa Jepang itu sedemikian rupa sehingga dapat dipakai sebagai alat untuk membantu mempercepat proses pembangunan Negara dan bangsa walaupun secara tidak langsung. Jadi bahasa asing khususnya bahasa Jepang merupakan salah satu saran yang sangat penting bagi manusia yaitu alat komunikasi.

Bahasa asing/ bahasa Jepang mempunyai fungsi untuk pengembangan ilmu pengetahuan dan teknologi dan untuk kepentingan komunikasi antar bangsa dalam rangka menjalin persahabatan dan perdamaian dunia.

Dengan Visit Indonesia Year thn 2017 Kota Manado sebagai Kota Pariwisata Dunia dan Even Internasional lainya yang dilaksanakan di Sulawesi Utara. Kebutuhan pramuwisata berbahasa Jepang akan meningkat sesuai dengan meningkatnya jumlah wisatawan Jepang berkunjung ke Sulawesi Utara Kocamatan RembokenKhususnya objek wisata di Minahasa.

Penyediaan pramuwisata berbahasa Jepang ini merupakan suatu kewajiban, mengingat para turis tentunya menginginkan pelayanan yang seoptimal mungkin, seperti mendapatkan informasi yang dikehendaki dalam bahasa Jepang atau berkomunikasi juga dengan bahasanya. Mengantisipasi kurangnya penyediaan pramuwisata maka Perguruan Tinggi khususnya Universitas Negeri Manado bekerjasama dengan karyawan objek wisata sumaru endo Remboken akan mengadakan pembelajaran bahasa Jepang praktis pada karyawan, guna untuk meningkatkan kualitas karyawan dalam menggunakan bahasa Jepang praktis khususnya menyangkut ketrampilan berbicara untuk menyapa tamu dengan hormat dengan menggunakan bahasa Jepang yang baik dan benar.

\section{B. Permasalahan Mitra}

Permasalahan yang teridentifikasi yang menjadi titik tolak kegiatan pengabdian pada masyarakat yang diusulkan ini terfokus pada beberapa masalah yang dihadapi oleh mitra yaitu:

1. Peningkatan kualitas dalam hal ketrampilan berbicara pada karyawan objek wisata sumaru endo Kecamatan Remboken.

2. Para karyawan kurang dalam ketrampilan berbicara bahasa Jepang yang baik dan benar dalam menyambut para tamu dalam pelayanan di objek wisata sumaru endo.

\section{TARGET DAN LUARAN}

\section{A. Target:}

Berdasarkan latar belakang pemikiran dan konteks permasalahan yang ada, maka pelaksanaan pelatihan ini bertujuan, terutama untuk menghasilkan Karyawan yang berpengetahuan, berkemampuan dan memiliki keterampilan berbicara bahasa Jepang yang baik dan benar.

Menerapkan model-model pengajaran yang kooperatif yang mudah diserap oleh pembelajar adalah upaya pengajar untuk mencapai tujuan yang diharapkan yaitu dapat menguasai empat keterampilan berbahasa yakni; keterampilan berbicara, membaca, menulis, menyimak.

\section{B. Luaran}

Luaran yang diharapkan melalui pelaksanaan kegiatan pengabdian pada masyarakat ini adalah sebagai berikut: 
1. Peningkatan kualitas sumber daya manusia yakni Karyawan di objek wisata sumaru endo Kecamatan Remboken.

2. Melalui kegiatan ini diharapkan para karyawan dapat memiliki pengetahuan yang positif dalam rangka upaya peningkatan kemampuan berbicara dengan menggunakan model pembelajaran yang cocok, sehingga karyawan tidak meras bosa. Dan dapat menghasilkan karyawan yang handal terampil dalam pelayanan tamu dengan menggunakan bahasa Jepang yang baik dan benar.

\section{METODE PELAKSANAAN Metode Kegiatan}

Pelaksanaan PKM ini adalah penggunaan multi media berupa power point dengan menggunakan Lcd dengan menggunakan modelmodel pengajaran kooperatif bagi Karyawan . Kegiatan ini bertujuan untuk membekali pengetahuan pengajaran Bahasa Jepang yang praktis dan efektif. Sehingga ketika timbul permasalahan-permasalahan dalam pelayanan dengan orang asing khususnya orang Jepang dapat diatasi.

Berdasarkan permasalahan di atas sehingga dapat disimpulkan perlunya mengadakan pelatihan pembelajaran bahasa Jepang praktis pada Karyawan di objek wisata Kecamatan Remboken Sulawesi Utara.

\section{Prosedur Pelaksanaan}

Pelaksanaan kegiatan ini pertama bagi Karyawan dibagi kelompok menjadi 3 kelompok yang masing-masing diketuai oleh seorang ketua kelompok dan terdiri dari Karyawan objek wisata, dengan pembelajaran bahasa Jepang praktis sebagai berikut :

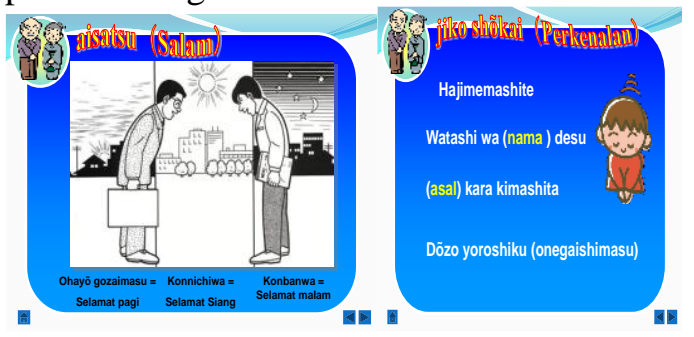

\section{HASIL DAN PEMBAHASAN}

Kegiatan pembelajaran Bahasa Jepang praktis pada karyawan Objek wisata sumaru endo dilaksanakan pada tanggal 28-29 April 2019 di desa Leleko Kecamatan Remboken. Metode yang digunakan dalam kegiatan pembelajaran
Bahasa Jepang praktis ini yang dilaksanakan dengan menggunakan metode Active learning dengan pokok permasalahan yang disesuaikan dengan tujuan yang ingin dicapai adalah yaitu metode active learning dengan menggunakan multimedia.

Materi-Materi yang disajikan adalah sebagai berikut:

\section{Hakikat Belajar dan Pembelajaran}

Pengajaran merupakan suatu kegiatan atau upaya membantu para siswa mengembangkan kemampuan, pengetahuan, dan keterampilan dalam suatu bidang tertentu, Ibrahim dan Syaodih (1992:2) kegiatan pengajaran tidak sesederhana membeli pakaian. Walaupun tidak sekompleks membangun sebuah kota, tetapi kegiatan ini membutuhkan perencanaan yang seksama dan dibuat secara tertulis.

Dengan lajunya perkembangan dewasa ini khususnya dalkam bidang pendidikan, telah banyak ahli yang mengungkapkan tentang teori belajar.Para ahli pendidikan telah berusaha merumuskan definisi tentang belajar dilihat dari berbagai segi.Berikut ini dikemukakan tentang beberapa pendapat para ahli mengenai pengertian belajar itu.

Para ahli mengenai teori belajar modern menemukakan dan merumuskan pengertian belajar sebagai berikut, belajar adalah suatu bentuk perubahan dalam diri seseorang yang dinyatakan dalam cara-cara bertingkah laku yang baru berkat pengalaman dan latihan (Hamalik, 1982:28). Tingkah laku yang baru itu misalnya dari tidak tahu menjadi tahu, timbulnya pengertian-pengertian baru, perubahan dalam sikap, kebiasaan-kebiasaan, keterampilan, kesanggupan menghargai, perkembangan sifatsifat sosial emosional, dan pertumbuhan jasmani.

\section{Bahasa Jepang}

Bahasa merupakan alat komunikasi yang paling efektif untuk menyampaikan gagasan, pikiran.Setiap hari manusia selalu berkomunikasi dengan sesamanya. Mitra komunikasi bermacam-macam, bisa dengan seseorang yang latar belakang sosialnya sama ataupun yang berlainan. Bahasa adalah sistem bunyi ujaran yang bersifat manasuka yang dapat digunakan dalam komunikasi interpersonal oleh sekumpulan orang. Sebagai alat komunikasi bahasa disampaikan melalui dua cara yaitu bahasa lisan dan bahasa tulisan. Setiap bahasa memiliki pedoman penggunaan atau tata aturan tertentu yang sebaiknya dipelajari agar dapat digunakan dengan baik dan benar sehingga dapat 
menimbulkan respon (feed back) yang baik antara pengguna bahasa tersebut.

Dengan masuknya perdagangan bebas, maka persaingan perdagangan dengan negara lain menjadi begitu ketat. Oleh karena itu bahasa menjadi salah satu aspek yang sangat penting, karena bahasa merupakan salah satu alat komunikasi yang sering digunakan. Bahasa yang sering di gunakan antara lain adalah bahasa Jepang. Maka agar tidak ketinggalan dengan perkembangan dunia yang semakin modern ini, kita semua yang ingin maju, harus mempersiapkanya dalam persaingan di era perdagangan bebas ini, yaitu dengan belajar bahasa Jepang. Perkembangan zaman banyak menimbulkan perubahan dan kemajuan dalam berbagai segi kehidupan dalam masyarakat. Antara lain ilmu pengetahuan dalam aspek sosial, politik, ekonomi, industri dan sebagainya. Perkembangan dalam berbagai lapangan kerja, merupakan salah satu masalah yang sering terjadi sekaligus peluang sebagai akibat perubahan dan kemajuan.Tuntutan kehidupan di zaman modern ini lebih tinggi dan lebih kompleks hal ini menyebabkan munculnya persyaratan tertentu bagi setiap orang yang ingin memasuki dunia pekerjaan.Dalam proses pembelajaran bahasa, kemahiran berbahasa dapat diamati dengan melihat kemampuan pada "empat macam keterampilan berbahasa yaitu keterampilan repsentif yang terdiri dari keterampilan membaca dan mendengar maupun keterampilan produktif yang terdiri atas keterampilan menulis dan berbicara.Ketrampilan berbicara adalah kemampuan mengungkapkan pendapat atau pikiran dan perasaan kepada seseorang atau kelompok secara lisan, baik secara berhadapan ataupun dengan jarak jauh.Moris dalam Novia (2002) menyatakan bahwa berbicara merupakan alat komunikasi yang alami antara anggota masyarakat untuk mengungkapkan pikiran dan sebagai sebuah bentuk tingkah laku sosial.

Bahasa dibagi dua: (1) Lisan (話し言葉 ) bentuk bahasa yang dipakai pada waktu tukar menukar informasi secara lisan dalam berbagai kegiatan kehidupan sehari-hari yang dilakukan dengan menggunakan alat ucap manusia dengan bantuan udara pernapasan. (2) Tulisan ( 書き言 葉) bentuk bahasa yang dipergunakan pada waktu tukar menukar informasi secara tertulis menggunakan huruf dalam berbagai kehidupan sehari-hari yang dilakukan dengan menggunakan huruf-huruf yang dapat diterima, dibaca, dan dimengerti oleh penerima informasi tersebut.
Keduanya memiliki tujuan yang sama yaitu untuk menyampaikan ide, pikiran, pendapat, perasaan, berita, dan sebagainya. Menurut Iwabuchi (1989:180). Bahasa Jepang adalah bahasa yang dapat dinyatakan dengan tulisan yang menggunakan huruf-huruf (kanji, hiragana, katakana, romaji).

Bahasa Jepang memiliki beberapa jenis huruf yaitu hiragana, katakana dan kanji.Tentu saja ke semua jenis huruf itu memiliki perbedaan dalam penggunaanya. Huruf dibagi dua:

1. Hyoo'i moji

Huruf yang dimulai dari gambar untuk menunjukkan isi atau arti suatu hal atau perkara, lalu ditentukan cara-cara pengucapannya berdasarkan kebiasaan atau adat istiadat masyarakat pemakainya Contoh: Kanji

2. Hyoo'on moji

Huruf yang hanya menyatakan bentukbentuk pengucapan yang tidak memiliki arti tertentu

Iwabuchi (1989:280-281) membagi Hyoo'on Moji menjadi dua:

1. Onsetsu Moji

Huruf yang menyatakan sebuah silabel seperti huruf hiragana dan katakana.Huruf Hiragana dulunya digunakan oleh para wanita Jepang (makanya bentuk tulisannya halus). Sedangkan penggunaanya adalah untuk:

- kata keterangan

- Perkataan dimana kanjinya lama tidak digunakan atau bahkan sudah tidak diketahui

- digunakan untuk situasi yang formal.

Huruf katakana hanya digunakan oleh kamu lelaki (makanya bentuknya lurus-lurus).

Digunakan untuk kata-kata yang berasal dari bahasa asing yang kemudian diserap menjadi bahasa jepang.

2. Tan'on Moji

Menyatakan sebuah fonem seperti huruf latin.

Katoo (1991:215) mengatakan bahwa huruf yang menyatakan tulisan bahasa jepang adalah huruf kanji, hiragana, katakana. Selain itu, selain suuji (kansuuji dan san'yoo suuji) dan romaji, dipakai juga beberapa kigoo. Yang dimaksud dengan Suuji: tulisan-tulisan yang melambangkan bilangan. Suuji dibagi dua yaitu: 
1. Kansuuji, yaitu lambang bilangan bahasa Jepang yang ditulis dengan huruf kanji

2. San'yoo suuji / Arabia suuji, yaitu lambang bilangan bahasa Jepang yang ditulis untuk keperluan penghitungan-penghitungan.

Sedangkan yang dimaksud dengan Kigoo adalah tanda baca (pungtuasi) yang biasa dipakai dalam bahasa Jepang ragam tulisan.

Dalam proses pembelajaran bahasa, kemahiran berbahasa dapat diamati dengan melihat kemampuan pada "empat macam keterampilan berbahasa yaitu keterampilan repsentif yang terdiri dari keterampilan membaca dan mendengar maupun keterampilan produktif yang terdiri atas keterampilan menulis dan berbicara.Ketrampilan berbicara adalah kemampuan mengungkapkan pendapat atau pikiran dan perasaan kepada seseorang atau kelompok secara lisan, baik secara berhadapan ataupun dengan jarak jauh.Moris dalam Novia (2002) menyatakan bahwa berbicara merupakan alat komunikasi yang alami antara anggota masyarakat untuk mengungkapkan pikiran dan sebagai sebuah bentuk tingkah laku sosial.

Disinilah kekuatan multimedia dalam memaparkan pengertian kompleks menjadi sajian yang menarik dan mudah dipahami.

Multimedia telah mengembangkan proses pengajaran dan pembelajaran ke arah yang lebih dinamik. Kegiatan visualisasi seperti ini mempermudah pemahaman siswa terhadap contens yang diajarkan dan secara psikologis multimedia mampu memberikan tingkat kebermaknaan yang lebih tinggi dengan dukungan kemudahan pemahaman dan rasa senang ketika proses belajar berlangsung. Unsur kebermaknaan dan rasa senang merupakan elemen utama dalam pembelajaran yang baik. Dengan adanya multimedia pengajar dapat menggalakkan sistem pembelajaran yang kooperatif dan interaktif antara pembelajar dan pengajar karena bisa mengakomodasi keragaman modalitas belajar siswa baik audio, visual maupun kinestetik. Juga penyajian materi lebih efektif dan efesien serta dapat meningkatkan minat dalam belajar khususnya belajar KAIWA (percakapan).

Bahasa Jepang yang diajarkan sebagai berikut:

1. Persalaman (aisatsu)

Ohayou Gozaimasu : Selamat Pagi

Konnichi wa : Selamat Siang

Konban wa : Selamat malam

Sayounara : Selamat berpisah
Oyasumi nasai : Selamat beristirahat

Dewa mata : : Sampai jumpa lagi

2. Perkenalan

Hajimemashite (nama orang) Desu

Douzou yoroshiku (onegai shimasu)

Pola kalimat

watashi wa........desu

\section{KESIMPULAN}

Kegiatan pengabdian pada masyarakat dalam bentuk Penggunaan multimedia dalam pembelajaran Bahasa Jepang Praktis pada karyawan objek wisata sumaru endo Kecamatan Remboken telah dilaksanakan dengan baik

Pelaksanaan pelatihan ini telah mencapai tujuan yang direncanakan karena semua peserta dapat menguasai dan menggunakan bahasa Jepang dan tulisan Jepang yang sederhana guna untuk menunjang karyawan dalam (berkomunikasi )pelayanan wisata khususnya tamu orang Jepang.

\section{REFERENSI}

Andrew N. Nelson. 2006. Kamus Kanji Modern Jepang-Indonesia.Jakarta: PT Kesaint Blanc Indah Corp.

Gerlach V. G. dan Ely D. P. 1971.Teaching and Media Systematic Approach.Englewood Cliffs: Prentice Hall. Inc.

Hamalik Oemar. 1982. Media Pendidikan. Bandung: Alumni.

Margono S. 2003. Metode Penelitian Pendidikan. Jakarta: Rineka Cipta.

Nasution S. 1987. Metodologi Penelitian Naturalistik Kualitatif. Bandung: Tarsito.

Pangabean Maruli. 1981. Bahasa Pengaruh dan Peranannya.Jakarta: Gramedia

Raharjo. 1991. Media Pendidikan. Jakarta: PT Grafindo Persada.

Reseir, Robert A, dan Robert M. Gagne. 1970. Characteristics of Media Selection 
Models dalam Review of Educational Research. Boston.

Riduwan. 2003. Dasar-dasar Statiska. Bandung: Alfabeta.

Sadiman. S. Arief. 1986. Media Pendidikan. Jakarta: PT Raja Grafindo Persada.

Shalvelson. R. 1981. Statistical Reasoning for the Behavioral Science.Boston: Allyn \& Bacon.

Suharsimi Arikunto. 2002. Prosedur Penelitian Suatu Pendekatan Praktek. Jakarta: Rineka Cipta.
Surahmad Winarno. 1988. Pengantar Penelitian Ilmiah Dasar, Metode dan Teknik. Bandung: Tarsito.

Syamsudin. A. R. 1986. Sanggar Bahasa Indonesia. Jakarta

Walijah. 1996. Bahasa Indonesia Dalam Perbincangan. Jakarta IKIP Muhamadiah.

Yoshida Yasuo. 1999. Bahasa Jepang Sehari-hari (Japanese For Today). Jakarta: PT Grasindo. 